\title{
REKONSTRUKSI HUKUM SURAT BERHARGA DALAM PEMBANGUNAN SISTEM HUKUM NASIONAL
}

\author{
Kingkin Wahyuningdiah
}

Dosen Bagian Hukum Administrasi Negara FH Universitas Lampung

\begin{abstract}
Abstrak
Tujuan penelitian ini adalah melakukan analisis untuk mengetahui alasan terjadi pergeseran pemaknaan terhadap surat berharga, diperlukannya rekonstruksi Hukum Surat Berharga dalam rangka pembangunan sistem hukum nasional dan upaya yang dapat dilakukan untuk melakukan rekonstruksi Hukum Surat Berharga tersebut. Penelitian ini termasuk dalam penelitian doktrinal dengan tipe deskriptif, dengan menggunakan data sekunder yang bersumber dari bahan kepustakaan untuk diolah dan dianalisis secara kualitatif. Hasil penelitian menunjukan bahwa terjadinya pergeseran pemaknaan terhadap surat berharga adalah dimungkinkan dalam hubungannya dengan terjadinya perubahan sosial masyarakat. Dalam kondisi seperti itu dan demi terwujudnya kepastian hukum maka perlu segera dilakukan rekonstruksi terhadap Hukum Surat Berharga. Untuk melakukan rekonstruksi terhadap Hukum Surat Berhharga ada suatu upaya yang dapat dilakukan, yaitu dengan memposisikan hukum sebagai social engineering dan membuat peraturan yang mengarah kepada hukum yang responsif.
\end{abstract}

Kata Kunci: Rekonstruksi, Hukum Surat Berharga dan Sistem Hukum Nasional

\section{PENDAHULUAN}

Indonesia menjadi sebuah negara baru yang lahir setelah merebut kemerdekaan tanggal 17 Agustus 1945. Sejak saat itu, sebagai sebuah negara baru maka Indonesia melakukan perubahan-perubahan. Perubahan ini jika diperhatikan meliputi: $^{1}$ (1) penyusunan suatu struktur kekuasaan baru; (2) penciptaan suatu dasar kerohanian baru; (3) reorganisasi dari badanbadan atau lembaga;dan pembentukan norma- norma hukum baru guna melayani bekerjanya negara baru tersebut. Namun demikian, untuk melakukan penyususnan dan penataan atas

${ }^{1}$ Satjipto Rahardjo, Pemanfaatan Ilmu-Ilmu Sosial Bagi Pengembangan Inти Hukum, 2010, Yogyakarta: Penerbit Genta Publishing, hal. 97. perubahan- perubahan tersebut tidak bisa dilakukan dalam waktu sepuluh atau duapuluh tahun. Dengan kata lain, mengandung pengakuan, dibutuhkan waktu yang lebih lama untuk melakukan penyususnan dan selama itu kita akan senantiasa dapat menyebutnya suasananya sebagai suatu masa transisi. Dalam masa transisi seperti ini tidak mudah untuk mengkombinasikan antara yang tradisional dan yang moderen. Demikian juga dalam bidang pengaturan hukum pada berbagai segi kehidupan, di satu sisi Indonesia masih memberlakukan ketentuan hukum masa kolonial, disisi lain masyarakat telah mengalami perubahan dan hukum akan mencari bentuknya yang baru.

Untuk istilah masa transisi
yang


perubahan- perubahan ini dapat kita sebut sebagai masa atau proses pembangunan. Pembangunan adalah ${ }^{2}$ upaya sadar yang dilakukan untuk merubah suatu kondisi dari suatu tingkat yang dianggap kurang baik ke keadaan baru pada tingkat kualitas yang dianggap baik atau paling baik.

Keadaan seperti ini juga terjadi pada segi kehidupan yang bertalian dengan masalah ekonomi, khususnya kegiatan pemenuhan kebutuhan dengan menggunakan uang. Dalam sejarah perkembangan peradaban manusia, pernah dilalui satu fase yang disebut barter, yaitu pertukaran antara barang dengan barang yang dilakukan manusia untuk mencukupi kebutuhannya. Pertukaran barang dengan barang lalu bergeser dengan cara penggunaan uang sebagai alat bayar dalam transaksi perdagangan. Kini dalam dunia yang kian moderen, dimana manusia menghendaki segala sesuatunya lebih peraktis dan aman, maka alat bayar yang menggunakan mata uang digantikan atau digeser dengan menggunakan surat berharga berupa cek, wesel, surat sanggup, atau surat berharga dalam bentuk lainnya. Dalam KUHD Titel 6 diatur tentang Surat Wesel dan Surat Sanggup, sedangkan dalam Titel 7

\footnotetext{
${ }^{2}$ Niniek Suparni, Pelestarian, Pengelolaan dan Penegakan Hukum Lingkungan, 1992, Jakarta: Penerbit Sinar Grafika, h.36. Muchtar Kusumaatmadja, Pembinaan Hukum Dalam Rangka Pembangunan Hukum Nasional, 1986, Bandung: Bina Cipta, hal. 1. menjelaskan bahwa apabila diteliti, maka semua masyarakat yang sedang membangun selalu dicirikan oleh perubahan, bagaimanapun kita mendefinisikan pembangunan dan apapun ukuran yang kita pergunakan bagi masyarakat dalam pembangunan tersebut. Peranan hukum dalam pembangunan adalah untuk menjamin bahwa perubahan itu terjadi dengan suasana damai dan teratur.
}

diatur tentang Cek, Promes dan Kuitansi Atas Tunjuk. Ketentuanketuan KUHD mengenai surat berhaga tersebut sampai saat ini masih menjadi dasar hukum bagi penggunaan surat berharga di Indonesia karena setelah Indonesia merdeka, KUHD tetap diberkakukan berdasarkan Aturan Peralihan UUD1945.

Dalam ketentuan pasal-pasal yang termuat dalam Titel 6 dan Titel 7 KUHD tersebut tidak ditemukan konsep atau definisi surat berharga. Karenanya para ahli dengan merujuk pada ketentuan- ketentuan KUHD membuat semacam indikator untuk menyatakan bahwa suatu surat dapat dikatakan sebagai surat berharga, dengan melihat pada fungsinya, 3 yaitu dapat digunakan sebagai alat bayar, dapat diperjualbelikan dan sebagai bukti hak tagih pembayaran sejumlah uang. Dalam perkembangannya ternyata jenis surat berharga yang digunakan tidak lagi terbatas pada jenis surat yang diatur dalam KUHD tersebut, tetapi telah dikenal berbagai jenis surat-surat lain yang dalam beberapa peraturan perundangan disebut juga sebagai

\footnotetext{
${ }^{3}$ Kingkin Wahyuningdiah, Dimensi Hukum Surat Berharga. Edisi Revisi. Bandar Lampung: Penerbit Universitas Lampung, 2010, hal. 10, menulis bahwa menurut Scheltema surat atas tunjuk dan atas pengganti dikelompokan menjadi tiga, yaitu zakenrechtelijke papieren (surat-surat yang bersifat hukum kebendaan) adalah surat yang isi perikatan dasarnya adalah untuk menyerahkan barang yang terdapat dalam surat itu; lidsmaatshaps papieren (suratsurat tanda keanggotaan suatu persekutuan) yang isi perikatan dasarnya adalah hak-hak tertentu yang diberikan persekutuan kepada pemegangnya dan schuldvorderings papieren (surat-surat tagihan hutang) adalah surat yang berjudul Hukum dagang Tentang Surat-Surat Berharga. Bandung: Citra Aditya Bakti, 2003, hal. 9.
} 
surat berharga, seperti Bilyet Giro, Surat Kredit Berdokumen Dalam Negeri (SKBDN), Commersial Paper , Saham, Resi Gudang dan lain-lain surat yang ditetapkan sebagai surat berharga. Beberapa surat yang muncul dalam peraktik tersebut sebagaian masih memiliki persamaan fungsi dengan surat berharga yang diatur dalam KUHD, yaitu Bilyet Giro, SKBDN dan Commercial Paper, akan tetapi telah diatur secara terpisah dari KUHD, yaitu dalam bentuk kebijakan Bank Indonesia berupa Surat Keputusan Direksi Bank Indonesia. Tidak ada yang mengatur secara khusus tentang saham, tetapi Resi Gudang diatur dalam Undang-undang No.9 tahun 2006 Tentang Sistem Resi Gudang. Melihat perkembangan ini, ternyata terjadi suatu kesenjangan antara ketentuan KHUD mengenai surat berharga dengan beberapa surat yang timbul dan digunakan dalam peraktik sebagai surat berharga, karena ternyata dalam karakteristik surat yang muncul dalam peraktik sebagai surat berharga tersebut tidak memiliki kriteria fungsi sebagaimana dimiliki surat-surat berharga yang diatur dalam KUHD. Saham yang tujuan penerbitannya adalah sebagai tanda keanggotaan suatu persekutuan dan Resi Gudang yang tujuan penerbitannya adalah bukti atas penitipan barang di gudang ternyata disebut dan digunakan sebagai surat berharga.

Uraian tersebut menggambar-
kan betapa perubahan-perubahan
telah terjadi dalam memaknai surat
berharga, sehingga berdampak pada
munculnya berbagai peraturan untuk
mengaturnya. Beragamnya peraturan
hukum tentang surat berharga, di satu
sisi akan menimbulkan ketidak
pastian hukum dalam penanganan

kasus-kasus surat berharga, di sisi lain mungkin akan menimbulkan ketidak adilan bagi para penggunanya, apalagi jika dalam perkembangannya terus muncul jenis-jenis surat berharga yang diatur dalam peraturan atau kebijakan yang tersebar. Keadaan ini menggambarkan situasi transisi, dari keadaan hukum yang lama menuju kepada keadaan hukum baru yang diharapkan. Dalam situasi seperti ini, diperlukan kehadiran hukum baru yang mampu merekonstruksi kembali hukum surat berharga dengan melihat pada perubahanperubahan yang terjadi. Rekonstruksi dalam Bahasa Inggris reconstruction artinya pembangunan kembali. ${ }^{4}$ Pembentukan hukum baru yang memenuhi segala kepentingan sesuai perkembangannya sangat diperlukan, karena pembuatan undang-undang merupakan tahap bagi terlaksananya penegakan hukum. Dalam kaitan dengan tulisan ini berarti membangun kembali Hukum Surat Berharga, yaitu menata ulang hukum baru tentang surat berharga sesuai dengan perkembangan dan kebutuhan masyarakat. Pada tataran teori hukum kiranya kita dapat meminta bantuan teori fungsi dari Talcotts Parsons untuk menjelaskan tempat dan fungsi hukum pada masa transisi tersebut, teori sistem hukum dari Friedman untuk menjelaskan pentingnya pembaharuan peraturan hukum sebagai bagian dari seluruh sistem hukum yang ada, dan teori pembangunan hukum dari Roscoe Pound untuk melakukan kajian mengenai bentuk hukum yang dikehendaki.

\footnotetext{
4 Suwondo Admojo dan Darseno, Kamus Lengkap Inggris-Indosesia, Indonesia Inggris, 2010, Semarang: Widya Karya, hal. 286.
} 
Berdasarkan uraian tersebut, permasalahan yang dibahas adalah Mengapa dalam perkembang-annya terjadi pergeseran pemaknaan terhadap surat berharga, Benarkah rekonstruksi Hukum Surat Berharga diperlukan dalam rangka pembangunan sistem hukum nasional dan penegakan hukum di masa transisi ini, dan Upaya apa yang dapat dilakukan untuk melakukan rekonstruksi Hukum Surat Berharga tersebut?

\section{PEMBAHASAN}

\subsection{Penyebab terjadi pergeseran pemaknaan terhadap surat berharga}

Telah diuraikan di atas bahwa dalam KUHD yang menjadi dasar hukum bagi pengaturan surat berharga tidak ditemukan rumusan atau definisi surat berharga. Merujuk pada ketentuan Buku Kesatu Titel 6 dan Titel 7 KUHD yang mengatur tentang wesel, surat sanggup, cek, promes atas tunjuk dan kwitansi atas tunjuk, hanya dapat diidentifikasi tentang fungsi dari surat berharga, yaitu sebagai alat bayar, untuk diperjual belikan dan sebagai bukti hak tagih (surat legitimasi).

Kenyataannya dalam peraktik sampai saat ini muncul beberapa jenis surat yang disebut sebagai surat berharga. Sebagian dari jenis surat tersebut memiliki karakteristik dan fungsi yang hampir sama dengan fungsi surat berharga yang telah diatur dalam KUHD, surat-surat itu adalah Bilyet Giro, Surat Kredit Berdokumen dan Commercial Paper. Ketiga jenis surat ini diatur secara terpisah dalam masing- masing Surat Keputusan Direksi bank Indonesia. Selain ketiga surat tersebut, muncul jenis surat lainnya yang juga disebut- sebut sebagai surat berharga, seperti saham dan resi gudang,. Untuk saham belum ada peraturan khusus yang mengaturnya, tetapi resi gudang diatur dalam Undang-undang No.9 tahun 2006 tentang Sistem Resi Gudang.

Melihat fenomena tersebut memberi gambaran kepada kita bahwa untuk saat ini pemaknaan terhadap surat berharga telah mengalami pergeseran. Benarkah? Jawabnya tentu "ya", karena ternyata dari berbagai surat yang muncul dan disebut sebagai surat berharga ternyata tidak memiliki fungsi sebagai surat berharga sebagaimana dikehendaki oleh KUHD. Kita ambil contoh misalnya saham dan resi gudang. Saham adalah surat bukti keanggotaan suatu persekutuan, sedang resi gudang merupakan surat bukti penyimpanan barang di dalam gudang. Dalam Hukum Surat Berharga ada satu teori yang menjadi dasar untuk mengelompokan suatu surat termasuk atau tidak ke dalam jenis surat berharga, yaitu teori yang dikemukakan oleh Scheltema yang mengelompokan surat sanggup dan atas pengganti menjadi tiga kelompok besar, yaitu zakenrechtelijke lidmaatschaps papieren dan schulvorderings papieren. ${ }^{5}$

Merujuk pada teori tersebut, bahwa yang termasuk dalam kelompok surat berharga adalah surat yang "isi perikatan dasarnya untuk membayar sejumlah uang". Dalam Undang-undang No.9 tahun 2006 tentang sistem Resi Gudang, khususnya dalam penjelaan Pasal 2 ayat (1) dan ayat (2) dijelaskan

\footnotetext{
5 Selengkapnya lihat dalam Abdulkadir Muhammad, Hukum Dagang Tentang SuratSurat Berharga, 2003, Bandung: Penerbit P.T Citra Aditya Bakti, h.9
} 
bahwa, sebagai bukti kepemilikan Resi Gudang adalah surat berharga yang mewakili barang di gudang, ${ }^{6}$ sementara jika kita kaitkan dengan teori Scheltema tersebut di atas resi gudang termasuk dalam zakenrechtelije papierens yang disebut dengan istilah ceel (warrant). Kelompok surat yang tergolong sebagai surat yang bersifat hukum kebendaan ini, isi perikatan dasarnya adalah menyerahkan barang yang tersebut dalam surat itu. Demikian juga dengan saham, berdasarkan teori tersebut saham masuk dalam kelompok lidmaatschaps papierens, yaitu surat- surat tanda keanggotaan suatu persekutuan yang isi perikatan dasarnya adalah hak- hak tertentu yang diberikan oleh persekutuan kepada pemegangnya, misalnya hak suara, hak rapat, hak untuk mendapatkan deviden.

Jelas sudah bahwa untuk saat ini telah terjadi pergeseran pemaknaan terhadap surat berharga, sehingga muncul beberapa peraturan perundangan yang mengatur secara terpisah di luar KUHD terhadap keberadaan surat berharga ini. Pertanyaan berikutnya adalah mengapa hal itu terjadi? Jawaban sementara yang dapat diberikan adalah karena adanya perubahan sosial bangsa ini yang mungkin terjadi karena desakan-desakan ekonomi, politik atau budaya. Menurut teori Parsons, dalam suatu sistem masyarakat, hukum merupakan sub sistem yang memiliki fungsi entegratif. Sub sistem lainnya adalah kultur dengan fungsi

6 Iswi Hariyani, dan R. Serfianto, Resi Gudang Sebagai Jaminan Kredit \& Alat Perdagangan, 2010, Jakarta:Penerbit Sinar Grafika, h.12. Lihat juga dalam Undangundang No.9 tahun 2006 Tentang Sistem Resi Gudang primernya mempertahankan pola, politik dengan fungsi primernya mencapai tujuan dan ekonomi dengan fungsi primernya melakukan adaptasi. Antara hukum dan sub sistem lainnya tersebut terjadi keterhubungan sistemik.

Keterhubungan tersebut terjalin melalui terjadinya proses-proses diantara sub sistem tersebut. Memang tidak selalu perubahan dalam satu sub sistem akan menjadikan perubahan bagi sub sistem lainnya. Namun tidak demikian dengan hukum, dimana kemungkinan besar terjadi perubahan dalam hukumnya ketika terjadi perubahan dalam sub sistem budaya, potitik atau ekonomi.

Suatu kemungkinan terjadinya perubahan hukum ketika terjadi perubahan pada sub sistem lainnya adalah karena hukum melakukan pekerjaan- pekerjaan: ${ }^{7}$

(1) Merumuskan hubunganhubungan diantara anggotaanggota masyarakat dengan menunjukan perbuatanperbuatan apa saja yang dilarang dan mana yang boleh dilakukan;

(2) Mengalokasikan dan menegaskan siapa-siapa yang boleh menggunakan kekuasaan atas siapa berikut prosedurnya;

Penyelesaian sengketasengketa;

(4) Mempertahankan adaptasi masyarakat dengan cara

\footnotetext{
${ }^{7}$ Satjipto Rahardjo, Hukum dan Perubahan Sosial Suatu Tinjauan Teoritis Serta Pengalaman Pengalaman di Indonesia, 2009, Yogjakarta : Penerbit Genta Publishing, h.34
} 
mengatur kembali hubunganhubungan dalam masyarakat apabila keadaan berubah.

Selanjutnya

Satjipto menjelaskan, ${ }^{8}$ dari uraian mengenai pekerjaan hukum tersebut di atas, maka pekerjaan pada angka empat menunjukan betapa eratnya hubungan antara hukum dan perubahan sosial atau betapa pekanya hukum itu berhadapan dengan keadaan sosial tersebut. Sekalipun demikian, kiranya tidak kurang pula membuat hukum itu terbuka untuk menerima pengaruh dari perubahan sosial. Misalnya, apabila hukum harus merumuskan hubungan- hubungan di antara anggota masyarakat maka harus segera ditambahkan, perumusan itu dilakukan dengan cara mengangkatnya dari bahan-bahan yang terdapat dalam masyarakat. Sekarang, apabila terjadi perubahan sosial, maka perumusan hukum positip yang diangkat dari bahan hubungan- hubungan dalam masyarakat tentunya akan berbeda dari perumusan terdahulu. Untuk mempertahankan koherensi sistem yang baru, maka peraturan- peraturan yang lama pun perlu disesuaikan dengan yang baru.

Berdasarkan uraian tersbut kita memperoleh pemahaman bahwa perubahan hukum sangat erat hubungannya dengan terjadinya perubahan sosial. Mengenai penyebab terjadinya perubahan sosial sendiri tidak begitu saja dapat kita jelaskan tanpa mengetahui secara mendalam apa sebenarnya yang menjadi penyebab perubahan sosial tersebut. Akan tetapi, paling tidak dapat kita lihat sebagai awal terjadinya perubahan sosial dalam

\footnotetext{
${ }^{8}$ Ibid, h. 35
}

masyarakat itu misalnya karena terjadi perubahan dalam sistem ekonomi, sistem budaya atau sistem politik. Kemajuan teknologi informasi pada era globalisasi ini misalnya, akan menjadi penyebab awal berubahnya sistem ekonomi, sistem budaya atau bahkan sistem politik pada sekelompok masyarakat. Desakan- desakan kepentingan baik di bidang budaya, politik maupun ekonomi akan mendorong terjadinya perubahan sosial yang pada akhirnya mendorong untuk terjadinya perubahan hukum.

Berbagai kepentingan yang mendorong terjadinya perubahan harus diintegrasikan, agar tidak terjadi konflik diantara kepentingankepentingan tersebut. Fungsi integrasi inilah yang dalam teori Parsons disebut sebagai fungsi primer yang dimiliki oleh hukum. Dihubungkan dengan hal tersebut, maka terjadinya perubahan dalam memaknai surat berharga yang dibuktikan dengan adanya peraturan baru di bidang ini dapatlah untuk sementara kita anggap bahwa hukum disitu sedang memainkan fungsi integrasi terhadap perubahan sosial yang terjadi. Kiranya bisa diambil contoh sebagai bahan ilustrasi, bahwa desakan kepentingan ekonomi dalam dunia usaha akan mempengaruhi pergeseran pemaknaan surat berharga adalah ketika perusahaan membutuhkan dana bagi pengembangan usahanya.

Selama ini kebutuhan tersebut dapat dipenuhi dari pengucuran kredit melalui perbankan. Ketika sumber dana melalui kredit perbankan tersebut tidak lagi bisa digunakan untuk memenuhi kebutuhan tersebut, maka pengusaha atau dunia usaha mulai berfikir untuk menemukan jalan keluarnya. Saat 
itulah muncul ide untuk menerbitkan saham untuk dijual kepada masyarakat melalui pasar modal. Disini saham tidak lagi dikeluarkan semata-mata untuk tujuan keanggotaan seseorang terhadap suatu perusahaan, akan tetapi lebih dari itu tujuannya menjadi alat untuk pendanaan perusahaan. Demikian juga dengan resi gudang yang pada hakekatnya merupakan bukti kepemilikan barang di gudang, kini lebih banyak digunakan sebagai jaminan kredit bank. Nah, desakandesakan ekonomi semacam ini akhirnya menimbulkan kebutuhan untuk mengatur lebih jauh persoalanpersoalan tersebut kedalam aturan tertulis. Kemudian dalam peraturan tertulis yang dibuat tersebut menyatakan bahwa dua surat tersebut dinyatakan sebagai sura berharga.

Dalam keadaan yang demikian, terlihatlah bahwa kini masyarakat khususnya para pembentuk undangundang dan kebijakan telah memiliki pemaknaan terhadap surat berharga secara berbeda dengan konsep semula tentang surat berharga. Kondisi ini akan terus berlangsung selama masa transisi, sampai akhirnya suatu saat hukum surat berharga akan menemukan bentuknya sendiri.

\subsection{Rekonstruksi Hukum Surat Berharga diperlukan dalam rangka pembangunan sistem hukum nasional dan penegakan hukum di masa transisi}

Sebagaimana dijelaskan pada bagian awal tulisan ini, bahwa kata rekonstruksi dalam Bahasa Inggris reconstruction artinya pembangunan kembali. Keadaan membangun kembali ini memiliki makna bahwa sebenarnya bangunan itu semula sudah ada, dan kemudian dengan adanya perubahan sosial yang menyebabkan porak porandanya bangunan tersebut menyebabkan perlunya pembangunan kembali tersebut. Rekonstruksi di bidang Hukum Surat Berharga diperlukan dalam pembangunan sistem hukum nasional. Artinya, membangun kembali Hukum Surat Berharga merupakan upaya untuk membangun sistem hukum nasional ecara keseluruhan. Apa sebenarnya sistem hukum itu?

Dalam pengertian sistem terkandung di dalamnya hal-hal sebagai berikut: (1) terdiri dari bagian, unsur, elemen, komponen, (2) satu sama lain berinteraksi dan interdependensi yang tersusun secara sistematis sehingga merupakan satu kesatuan yang utuh (3) terdapat tujuan yang ingin dicapai sebagai hasil akhir (4) berada dalam suatu lingkungan yang kompleks. ${ }^{9}$

Hukum sendiri memiliki berbagai pengertian, salah satu pandangan tentang hukum adalah bahwa hukum merupakan suatu kumpulan aturan yang mempunyai otoritas untuk menyelesaikan berbagai persoalan. ${ }^{10}$

Pada penjelasan mengenai unsur-unsur dalam suatu sistem, bahwa unsur pertama dalam suatu sistem terdapat unsur, elemen, atau komponen dari unsur tersebut. Sebagaimana diuraikan dalam bagian kerangka teoritik di atas, Lawrence Friedman, menjelaskan bahwa dalam sistem hukum terdapat tiga

\footnotetext{
9 Yusriadi, Tebaran Kritis Hukum dan Masyarakat, 2010, Malang: penerbit Surya Pena Publishing, h. 51

10 Munir Fuady, Dinamika Teori Hukum, 2010, Bogor : Penerbit Ghalia Indonesia, h. 70
} 
unsur utama, yaitu struktur hukum, substansi hukum dan kultur hukum. Jadi, sistem hukum adalah suatu sistem yang di dalamnya mengandung ketiga unsur tersebut. Membangun sistem hukum nasional idealnya melakukan pembangunan dalam ketiga unsur yang terdapat dalam sistem hukum tersebut.

Lalu apa yang diartikan sebagai pembangunan? Di bagian awal telah diberi gambaran bahwa pembangunan adalah merupakan upaya sadar yang dilaksanakan untuk merubah suatu kondisi dari suatu tingkat yang dianggap kurang baik, ke kondisi baru pada tingkat kualitas yang dianggap baik, atau paling baik.

Menurut Barda Nawawi, dalam makalah yang disampaikannya pada kuliah umum pada Program Pascasarjana UBH 11, walaupun sudah berulang kali seminar hukum nasional diselenggarakan, namun tidak satupun dijumpai penjelasan tentang pengertian "pembangunan" itu sendiri. Yang umumnya diungkap adalah masalah yang berkaitan dengan pembangunan hukum nasionalnya itu sendiri (antara lain ruang lingkup/bidang/program/ tahapan pembangunan hukum nasionalnya).

Jadi, istilah "pembangunan" seolah-olah sudah diterima begitu saja sebagai istilah umum. Namun, dalam berbagai seminar terungkap, bahwa "pembangunan" sering diidentikkan atau terkait erat di dalamnya dengan berbagai istilah/masalah "pengembangan, pembaharuan, reformasi, pembinaan, penataan, pemantapan kembali, peninjauan, evaluasi". Jadi, tercakup di dalamnya pengertian

11 http://bardanawawi.wordpress.com/2009 /12/24/38, diakses tanggal 17 Desember 2010 Pukul 22.52. development, reform, renovation, rebuild, reconstuction, evaluation/re-evaluation".

Dalam kaitan dengan pembangunan hukum nasional yang bersifat komperhensif semacam itu ${ }^{12}$, permasalahan utama politik pembangunan hukum nasional antara lain adalah sebagai berikut: (1) memperbaharui atau mengganti peraturan dari masa kolonial yang masih berlaku melalui Aturan Peralihan UUD1945; dan (2) menciptakan hukum baru yang secara utuh bersumber pada Pancasila dan UUD 1945 (termasuk perubahan-perubahannya), sesuai dengan tuntutan dan perkembangan masyarakat pada tingkat nasional, regional, dan internasional dalam era globalisasi.

Melalui pemahaman tentang cakupan pembangunan sistem hukum nasional tersebut di atas, ternyata melakukan rekonstruksi terhadap salah satu bidang hukum termasuk di dalamnya. Meskipun dinyatakan bahwa melakukan pembangunan sistem hukum nasional idealnya dilakukan secara komperhensive, namun rasanya tidak mengurangi arti dari hakekat pembangunan itu jika kita melakukannya hanya pada bagian tertentu saja dari seluruh sistem yang ada, misalnya dengan melakukan rekonstruksi terhadap substansinya. Peraturan hukum materil adalah sosok output dari sistem hukum dan ia juga merupakan bagian dari seluruh proses berlangsungnya penegakan hukum. ${ }^{13}$

12 Satya Arinanto, dalam Jurnal Konstitusi vol.3 no.3, Sepember 2006 : Topik "Hukum Nasional, Reformasi, sebagaimana telah diakses melalui http://lib. atmajaya.ac.id/defaul.aspx? tabID=a\&id $=95922$.

13 Satjipto Rahardjo, Penegakan Hukum,2009, Yogyakarta: Genta Publihing, 
Untuk kepentingan penegakan hukum, maka hukum dibuat tidak sekedar untuk mengejar kepastian hukum, akan tetapi lebih dari itu tersirat pencapaian keadilan hukum dalam masyarakat. Ide hukum untuk keadilan dikemukakan oleh Gustav Radbruch.

Menurut Radbruch, ${ }^{14}$ hukum sebagai pengemban keadilan akan menjadi ukuran bagi adil tidak adilnya tata hukum. Tanpa keadilan, hukum tidak pantas disebut sebagai hukum. Begitu pentingnya peraturan hukum dalam kaitannya dengan proses penegakan hukum dan pencapaian keadilan, maka dalam membuat dan menciptakan hukum harus melihat pada kepentingankepentingan masyarakat sesuai juga dengan perubahan-perubahan yang terjadi.

Pada masa transisi ini, langkah penyempurnaan peraturan melalui rekonstruksi adalah salah satu yang diperlukan dari sekian banyak langkah pembangunan hukum secara keseluruhan. Jadi, rekonstruksi Hukum Surat Berharga menjadi penting untuk dilakukan pada masa transisi sekarang ini adalah selain untuk menunjang pelaksanaan penegakan hukum di bidang ini, pada saatnya akan berpengaruh pada pembangunan sistem hukum nasional secara keseluruhan. Kembali pada

h.24< menjelaskan: bahwa konsep pemikiran yang dipakai dalam penegakan hukum adalah sudah dimulai pada saat peraturan hukumnya dibuat atau diciptakan. Penegakan hukum adalah suatu proses untuk mewujudkan keinginan- keinginan hukum menjadi kenyataan. Keinginan-keinginan hukum adalah pikiran- pikiran badan pembuat undang-undang yang dirumuskan dalam peraturan hukum. Perumusan pikiran pembuat hukum yang dituangkan dalam peraturan hukum akan turut menentukan bagaimana penegakan hukum itu dijalankan.

${ }^{14}$ Opzit. Bernard, 2010, h.128 teori Friedman, bahwa dalam suatu sistem hukum terdapat struktur hukum, substansi hukum dan kultur hukum, maka melakukan rekonstruksi terhadap hukum tertulis (peraturan) surat berharga adalah tindakan melakukan pembangunan pada substanasi hukumnya.

\subsection{Upaya yang dapat dilakukan untuk merekonstruksi Hukum Surat Berharga}

Setelah dijelaskan mengenai pentingnya dilakukan rekonstruksi dalam bidang Hukum Surat Berharga, pada bagian ketiga ini akan dijelaskan upaya yang dapat dilakukan untuk melakukan rekonstruksi tersebut. Hal ini dimulai dari pemikiran terhadap dua aspek kerja hukum dalam masyarakat. Bahwa dalam masyarakat, hukum dapat bekerja sebagai sarana kontrol sosial dan sebagai sarana untuk melakukan perubahan.

Hukum sebagai sarana kontrol sosial menitik beratkan pada pemecahan masalah yang dihadapkan kepadanya secara konkrit, yaitu mengatur hubunganhubungan sosial yang ada, sedangkan hukum sebagai social engineering, , orientasinya tidak hanya ditujukan kepada pemecahan masalah yang ada melainkan berkeinginan untuk menimbulkan perubahan- perubahan dalam tingkah laku anggota- anggota masyarakat.

Dalam sejarah teori hukum, faham yang mendudukkan hukum sebagai social engineering ini adalah aliran sociological yang disponsori antara lain oleh Roscoe Pound. Sebagai pemikir sociological jurisprudence, Pound mengusulkan agar para ahli hukum beraliran sosiologis perlu memperhitungkan 
fakta sosial dalam pekerjaannya, apakah pembuatan hukum, penafsiran atau penerapan peraturan. $^{15}$

Dikatakan oleh Pound, ${ }^{16}$ "....to enable and to compel law making, and alsointerpretation of legal rules, to make more account, and more intelligent account, of the social facts upon which law must proceed and to wich it is to be applied,......."

Fokus utama Pound dengan konsep social engineering adalah interest balancing, dan karenanya yang terpenting adalah tujuan akhir dari hukum yang diaplikasikan dan mengarahkan masyarakat kearah yang lebih maju. ${ }^{17}$ Untuk mengarahkan masyarakat kearah yang lebih maju itu hukum akan memuat hal-hal yang dapat mewujudkan kearah itu. Menyadari

bahwa perkembangan hukum akan dipengaruhi oleh perubahan sosial yang terjadi dalam masyarakat, maka tidak berlebihan kiranya bahwa untuk melakukan rekonstruksi terhadap hukum, hal yang dapat dilakukan adalah dengan mendudukan hukum sebagai social enggineering atau sebagai agen perubahan.

Dalam melakukan fungsinya tersebut, maka hukum harus melihat pada situasi yang memungkinkan terjadinya perubahan dalam masyarakat. Hukum benar- benar ditujukan untuk kepentingan masyarakat , karena hukum bukan hanya hasil ciptaan masyarakat, tetapi menciptakan masyarakat. Oleh

\footnotetext{
15 Ibid. H.187

16 Dikutip dari, Satjipto Rahardjo, Hukum Progresif Sebuah Sintesa Hukum Indonsia,2009, Yogjakarta: Penerbit Genta Publishing, h. 8

${ }^{17}$ Bernard L.Tanya, 2007, ibid hal.188
}

karena itu, maka upaya dalam melakukan rekonstruksi hukum diarahkan untuk menuju pada hukum yang resposif, yakni hukum yang bersifat terbuka terhadap perubahanperubahan dalam masyarakat. Ide hukum yang responsif digagas oleh Nonet-Selznick ditengah-tengah kritik pedas Neo-Marxis terhadap liberalism legalism.

Menurut Nonet- Selznick, ${ }^{18}$ perubahan sosial dan keadilan sosial membutuhkan tatanan hukum responsif. Konsep pandangan Nonet dan Selznick, mengenai hukum yang responsif adalah $:^{19}$ untuk mengatasi kekakuan dan tak sensitifnya hukum terhadap perkembangan sosial, senantiasa dikurangi kewenangan membuat hukum diserahkan kepada unit-unit kekuasaan yang lebih rendah, agar lebih memahami inti persoalan masyarakat.

Kebutuhan ini sesungguhnya juga telah menjadi tema utama dari semua ahli yang sefaham dengan semangat fungsional, pragmatis, dan semangat purporsif (berorientasi pada tujuan), seperti halnya Roscoe Pound, para penganut paham realisme hukum, dan kritikus-kritikus kontemporer.

Nonet dan Selznick melalui hukum responsif, menempatkan hukum sebagai sarana respons terhadap ketentuan- ketentuan sosial dan aspirasi publik. Sesuai dengan sifatnya yang terbuka, maka tipe hukum ini mengedepankan akomodasi untuk menerima perubahan- perubahan sosial demi mencapai keadilan dan emansipasi publik. Kepedulian terhadap akomodasi aspirasi sosial,

${ }^{18}$ Opzit, Bernard L.Tanya. 2010, h.204-205

${ }^{19}$ Sabian Usman,Menuju Penegakan Hukum Responsif, 2010, Yogyakarta: Penerbit Pustaka Pelajar, h.30 
menyebabkan teori ini masuk dalam wilayah sociological jurisprudence.

Merujuk pada paham tersebut di atas, maka dalam melakukan rekonstruksi terhadap Hukum Surat Berharga hendaknya dilakukan melalui upaya bersifat terbuka terhadap segala perubahan yang terjadi, namun demikian dalam menuju hukum modern dimasa yang akan datang, pembentukan hukum baru tetap berpedoman pada Pancasila sebagai idealisme bangsa dan tujuan negara sebagaimana tertuang dalam Pembukaan UUD 1945.

Dengan demikian, wajah Hukum Surat Berharga khususnya dan Hukum Nasional pada umumnya di tengah-tengah keterbukaannya terhadap perubahan sosial yang terjadi, tetap berpegang pada idealisme bangsa dan berdasar pada konstitusi.

\section{Penutup}

\subsection{Simpulan}

Berdasarkan hasil pembahasan terhadap permasalahan yang diajukan dalam makalah ini, maka dapat disimpulkan hal- hal sebagai berikut:

(1) Terjadinya pergeseran pemaknaan terhadap surat berharga oleh masyarakat dan pembuat peraturan perundangan (dalam hal ini Bank Indonesia dan badan pembuat undangundang) jika dikaji dengan menggunakan teori struktural fungsional dari Talcott Parsons, maka hal tersebut dimungkinkan karena adanya keterhubungan dengan terjadinya perubahan sosial masyarakat. Perubahanperubahan tersebut dapat terjadi pada sub sistem budaya, politik atau ekonomi. Tekanan-tekanan kepentingan yang datang dari subsistem budaya, politik, dan ekonomi yang menyebabkan terjadinya perubahan sosial masyarakat, akhirnya berdampak pada berubahnya subsistem hukum.

(2) Akibat dari terjadinya pergeseran pemaknaan terhadap surat berharga adalah keluarnya beberapa peraturan hukum yang mengatur surat berharga di luar KUHD. Oleh karena itu, terdapat dua kelompok sumber hukum surat berharga, yaitu KUHD sebagai warisan kolonial dan beberapa produk hukum nasional. Sepanjang masa transisi, keberagaman pengaturan tersebut masih dimungkinkan sampai pada suatu saat Hukum Surat Berharga menemukan bentuknya sendiri. Selama itu pula dikhawatirkan akan menimbulkan persoalan kepastian hukum di dalam penegakan hukumnya. Dalam kondisi seperti itu perlu segera dilakukan rekonstruksi terhadap Hukum Surat Berharga, tujuannya adalah agar tersusun Hukum Surat Berharga yang baru sebagai produk nasional yang dapat lebih menjamin kepastian hukum. Tahap pembentukan undang- undang juga merupakan bagian dari seluruh proses penegakan hukum, karena sesungguhnya penegakan hukum telah dimulai saat pembuatan undang-undang. Dikaitkan dengan teori Lawrence Friedman tentang sistem hukum, kegiatan 
melakukan rekonstruksi hukum sertulis ini merupakan bagian dalam melakukan perubahan dari sistem hukum, karena peraturan merupakan salah satu unsur dari sistem hukum, yaitu unsur substansi hukum.

(3) Untuk melakukan rekonstruksi terhadap Hukum Surat Berhharga ada suatu upaya yang dapat dilakukan, yaitu dengan memposisikan hukum sebagai social engineering sebagaimana digagas oleh Roscoe Pound. Dengan begitu, substansi hukum yang akan direkonstruksi itu disusun sesuai perubahan dalam masyarakat, hukumnya harus bersifat terbuka terhadap perubahan yang ada. Artinya, untuk melakukan rekonstruksi di bidang Hukum Surat Berharga harus diupayakan mengarah kepada hukum yang responsif terhadap perubahan dalam masyarakat sebagimana dikemukakan oleh Nonet dan Selzinck.

\subsection{Rekomendasi}

\section{(1) Teoritik}

Makalah ini mencoba melakukan kajian terhadap gagasan untuk melakukan rekonstruksi Hukum Surat Berharga. Kajan dimulai dengan membahas mengenai hal yang memungkinkan terjadinya perubahan konsep tentang surat berharga, kemudian dilanjutkan dengan pembahasan mengenai perlunya rekonstruksi peraturan hukum surat berharga dan terakhir mengenai upaya yang dapat dilakukan dalam melakukan rekonstruksi tersebut. Oleh karena itu, kajian didasarkan pada penggunaan teori Talcott Parsons, Lawrence M Friedman dan Roscoe Pound serta Nonet dan Selzinck. Kajian ini diharapkan dapat memberikan sumbang saran terhadap pengembangan teori dalam Hukum Surat Berharga.

\section{(2) Praktis}

Secara praktis rekomendasi ditujukan kepada pembuat undangundang, agar dalam pembentukan Hukum Surat berharga yang baru, diarahkan pada hukum responsif, yaitu hukum yang terbuka terhadap perubahan dalam masyarakat. Hal ini karena pembentukan hukum harus melihat pada tujuannya, yaitu untuk melayani kepentingan masyarakat. Lebih dari itu, karena pembentukan undang-undang merupakan awal dimulainya penegakan hukum.

\section{DAFTAR PUSTAKA}

Admojo, Suwondo dan Darseno. 2010. Kamus Lengkap Inggris-Indosesia, Indonesia Inggris. Widya Karya, Semarang

Ali, Achmad. 2010. Menguak Teor Hukum i (Legal Theory) dan Teori Peradilan (Judicial Prudence) Termasuk Interpretasi Undang- Undang (Legisprudence). Penerbit Kencana, Jakarta

Fuady, Munir. 2010. Dinamika Teori Hukum. Ghalia Indonesia, Bogor

Denzim, K Norman dan Yvonna S Lincoln. 2009. Handbook of Qualitative Research. Diterjemahkan oleh Dariyanto, Badrus Samsul 
Fata, Abi dan John Rinaldi. Pustaka Pelajar ; Yogyakarta

Moleong, Lexy. 2010. Metodologi Penelitian Kualitatif. Edisi Revisi. Penerbit P.T Remaja Rosdakarya, Bandung

Muhammad, Abdulkadir. 2003. Hukum dagang Tentang Surat-Surat Berharga. Citra Aditya Bakti, Bandung

Kusumaatmadja, Muchtar. 1986. Pembinaan Hukum Dalam Rangka Pembangunan Hukum Nasional. Bina Cipta, Bandung

Lawrence,M.Friedmen, M Lawrence. 2009. Sistem Hukum Prespektif Ilmu Sosial, terjemahan M. Khodzim. Nusa Media, Bandung

Rahardjo, Satjipto.2009. Penegakan Hukum Suatu Tinjauan Sosiologis. Genta Publishing: Yogyakarta.

Rahardjo, Satjipto.2009. Hukum Progresif Sebuah Sintesa Hukum Indonsia. Genta Publishing, Yogyakarta

Rahardjo, Satjipto. 2009 Hukum dan Perubahan Sosial Suatu Tinjauan Teoritis Serta Pengalaman- Pengalaman di Indonesia. Genta Publishing, Yogyakarta

Rahardjo, Satjipto. 2010. Pemanfaatan Ilmu-Ilmu Sosial Bagi Pengembangan Inmu Hukum, 2010, Genta Publishing, Yogyakarta
Ritzer, George. 1975. Sociology: A Paradigm Science. Allyn Bacon, Boston

Suparni, Niniek. 1992. Pelestarian, Pengelolaan dan Penegakan Hukum Lingkungan. Sinar Grafika, Jakarta

Tanya, L Bernard; Yoan N. Simanjuntak; Markus Y Hage. 2010. Teori Hukum Strategi Tertib Manusia Lintas Ruang dan Generasi. Genta Publishing, Yogyakarta

Utsman, Sabian. 2010. Мепијu Penegakan Hukum Responsif. Yogyakarta: Penerbit Pustaka Pelajar

Wahyuningdiah, Kingkin. 2007. Dimensi Hukum Surat Berharga.Edisi Revisi. Universitas lampung, Bandar Lampung

Yusriadi. 2010. TebaranPemikiran Kritis Hukum \&Masyarakat. Surya Pena Gemilang, Malang

http://bardanawawi.wordpress.com/2 009/12/24/38, diakses tanggal 17 Desember 2010 Pukul

Arinanto, Satya dalam Jurnal Konstitusi vol.3 no.3, Sepember 2006 : Topik "Hukum Nasional, Reformasi, sebagaimana telah diakses melalui http://lib. atmajaya.ac.id/defaul.aspx? tabID=a\&id $\quad=95922$. 